\title{
HUMAN CAPITAL AND FINANCIAL CAPITAL IN THE ATLANTIC SPACE FROM AMERICA TO CATALONIA, 1829-1855
}

Yolanda Blasco Martel (Universitat de Barcelona - UB

Departament d'Història i Institucions Económiques

Facultat d'Economia i Empresa

Universitat de Barcelona

Av. Diagonal, 690

08000 BARCELONA (Spain)

Tfn: 0034934035829

yolandablasco@ub.edu

Martín Rodrigo Alharilla (Universitat Pompeu Fabra -UPF)

Departament d'Humanitats Universitat Pompeu Fabra Carrer de Ramon Trias Fargas, 2508005

BARCELONA (Spain) Tfn:

0034935422660

martin.rodrigo@upf.edu 


\section{ABSTRACT:}

Spanish emigration to America during the last two decades of the eighteenth century and the first half of the nineteenth century gave rise to the figure of the "indiano" or "americano" in Spain — those men (and women) who returned to the peninsula with huge fortunes. In this article, we look at the roles played by indianos in Catalonia's financial development. Our research indicates that returnees not only made important investments in the Catalan economy; they exerted an impact that, although harder to quantify, was equally significant: the deployment of their human capital, constituted by extensive international commercial and financial expertise and participation in social and business networks, evidenced in multiple alliances and businesses set up in the peninsula. Centered on the financial sector, the article shows that indianos were thus key players in the modernization of Catalan finances through the first half of the nineteenth century.

Keywords: return migrants; human capital; finances; indianos; Catalonia. 
Throughout the first half of the nineteenth century, emigrants who returned to Spain after having spent a significant part of their lives in the New World were called "indianos", a word whose definitions in the dictionary of the Real Academia de la Lengua Española, include "those who return rich from America." Indeed, the prevalent presence of wealthy returnees across many Spanish towns and cities during the late eighteenth and early nineteenth centuries firmly planted the indiano archetype in the collective imagination of the period, as reflected in its literature and architecture. However, the impact of return emigrants went well beyond culture, for, as various scholars have shown, it entailed a strong and far-reaching influence in the economic activity of the regions where they resettled. ${ }^{1}$ But exactly how far did such an influence go? Can it be measured? Can we identify and apply variables to gauge the influence of return emigration on the Spanish economy, both quantitatively and qualitatively? In this article, we have tried to answer these questions by limiting our research to a concrete case: the financial system in Catalonia in the early nineteenth century (specifically, between 1829 , when the first Spanish Commerce Code was promulgated; and 1855, when the first liberal laws that encouraged railroads, banking and credit societies were passed). These decades constitute the most crucial period of the Catalan financial sector's modernization, so that we dare say that return migrants' capital — financial, and otherwise — helped shape this process.

The participation of indianos or americanos (as they were also called in some parts of Spain) in Catalan economic activity has been amply studied. Various authors have shown, for instance, that indianos' financial capital was decisive in the industrialization of specific areas or towns, such as Vilanova i la Geltrú ${ }^{2}$ while others have written broader analyses on indiano investments in Catalonia's nineteenth century economy. ${ }^{3}$ And although we do not 
know the exact sum of American capital invested in the region, extensive research shows that it was significant.

But researchers' preoccupation with the volume of indianos' material capital has perhaps kept them from addressing another key aspect of their economic participation: their intangible contributions, their human capital. Xose Manoel Núñez Seixas has addressed this aspect of return emigration's impact for the whole of Spain, but there are very few other studies to have done so, and none deal specifically with Catalonia ${ }^{4}$. And if measuring the impact of indianos' capital investments is difficult, because neither persons nor funds were identified as "indianos" in companies' and government records, measuring the impact of their intangible contributions is even more complicated. For one thing, the scarce data available tends to be qualitative, which means that a quantitative analysis can only be carried out after retrieving what seem like microscopic details of documents long and meticulously considered.

When deciding whether to emigrate, and whether to return, people take into account monetary and non-monetary factors. ${ }^{5}$ And they also carry baggage that contains more than just objects: they carry with them their ideas, their experiences, their knowledge, their beliefs. But even if we only looked at economic aspects of return migration, we should take into account that people brought back more than just the money accumulated during their lives in America: they brought back a set of intangibles. Generally speaking, intangibles are certain assets that, without being registered as part of a company's physical or material capital, are essential to its operations, including patents, trademarks, and organizational designs, but also managers' and employees' knowledge and abilities; relations with clients; the company's reputation, etc. As we can see, intangibles include social capital, intellectual capital, and, as the sum of both and more, human capital, where the latter is defined as the 
set of abilities and capacities accumulated by persons as a result of their life cycle, both inside and outside their work experience. ${ }^{6}$ Deployed by those who embody them, these aptitudes, skills and competences contribute to raise productivity and innovation not only in their workplaces but also in their wider societies. In microeconomic terms, the most fundamental of these are the knowledge and abilities related to a person's profession, as well as the networks that they have inserted themselves in and contributed to constructthat is, the numerous contacts and acquaintances that they have, especially of people in positions that can help their businesses.

Accordingly, this article's objective is to measure the tangible impact that indianos had in the modernization of the Catalan financial system between 1829 and 1855 by taking into account the human capital that they deployed as well as the monetary and chrematistic investments that they carried out. We chose to focus on the financial sector because it underwent some of the most fundamental transformations and innovations that swept Spanish society during this period, and Catalan society more specifically. On the one hand, the Bank of Barcelona, a note issuing bank with a modernizing zeal, was born during this period. ${ }^{7}$ The insurance companies founded in these decades differed completely from those that had proliferated in the eighteenth century. ${ }^{8}$ And although this subject has been addressed by Carles Badenes, we approach it from an entirely different perspective and a much shorter temporal framework, so that what can be learned from our research is essentially different from his. ${ }^{9}$

The text is organized in three parts. In the first, we describe the main vectors that deeply transformed the Catalan economy during the second quarter of the nineteenth century. In the second part, we look at the monetary returns produced by financial enterprises constituted as joint-stock companies. And finally, we look at the role played by the human 
capital that indianos invested in the Catalan financial sector. We end the article with a brief set of conclusions in which we make clear the importance of return migration from the Americas in the Catalan financial system, in terms of the monetary wealth that it injected, the new knowledge and experiences that it provided through the men and women who held it, and the business networks that exponentially multiplied trade and growth of financial assets.

\section{The Catalan economy (1829-1855): change and innovation in industry, trade and}

\section{finances}

In the years between the enactment of the first Spanish Commercial Code in 1829, and the so-called "bienio progresista" (characterized by a noted legislative zeal) of $1854-1856$, the Catalan economy and society underwent profound transformations. They were not easy years, for the devastating civil war that wracked all of the Spanish territory caused enormous destruction of life and of the productive capacity that sustained life. Yet despite the war, these twenty-five years were characterized by economic growth and, above all, by the irreversibility of the modernization process that swept through the country's economy and institutions.

Catalonian industries adopted rather quickly the cutting-edge technology of steam-engines and machines that were revolutionizing British and other countries' economies and societies. The pioneers were the Bonaplata brothers, who on November of 1833 inaugurated the first steam-powered factory of peninsular Spain in the city of Barcelona. Soon after, steam-powered factories began to modify the social and urban landscape of the principality. In a relatively brief period, Catalonia became industrialized, the true factory of Spain. ${ }^{10}$ The process, predictably, was not without its tensions. On July of 1855 , in the 
middle of the bienio progresista, Barcelona and the main industrial centers of the country witnessed the first general strike in the history of Spain. ${ }^{11}$ This conflict epitomized the upheaval and social stress that accompanied an accelerated transformation that altered the existing class structure, not only with the emergence of new social classes, such as the industrial proletariat, but also with the disturbance of older class relations.

The first railroad built on peninsular Spain was also inaugurated in Catalonia, joining Barcelona with the town of Mataró on October of 1848. This was soon followed by others, such as the Barcelona - Molins de Rei line (1853); the Barcelona - Granollers line (1854), and the line that eventually connected Barcelona to Zaragoza, passing through Sabadell (1855) and Terrassa (1856). ${ }^{12}$ These railways' construction and operation was intimately related with the development of limited liability companies (most of them established as joint-stock companies), and therefore, encouraged the association of private capitalholders. $^{13}$

Steam-power was not limited to industry or railways - it was also applied to navigation. The first instance of this innovation in Catalonia goes as far back as March of 1830, when Ferdinand VII granted businessman Juan Reynals the privilege to import a steamship from England and set up a shipping line between Barcelona and Ciutat de Mallorca. This was the birth of the pioneering Compañía Catalana de Vapor (transformed in 1841 into the Sociedad de Navegación e Industria), which was followed by other shipping companies, such as the limited partnerships Bofill Martorell y Cía., Pablo M. Tintoré y Cía., Hispano Alemana de Vapores and the Compañía Catalana de Vapores Costaneros, among others. Thanks to the activity of these companies, the port of Barcelona had more registered steamships than all other Spanish ports. In fact, between 1834 and 1870, a total of fifty-nine steamships were registered in the city. ${ }^{14}$ 
During those years, this powerful merchant marine and potent commercial sector adapted their main activities around the needs of Catalan industry. ${ }^{15}$ After the first years of the (misnamed) war of independence, and especially, the effects of the loss of the Spanish empire in continental America between 1810 and 1825, the Catalan merchant marine was capable of adapting to the demands of the principality's industrial activity. This adaptation included a shift in the ultramarine projection of the Catalan economy and society, not its disappearance. Following the new parameters presented by the changed political reality, Catalan traders reoriented the American dimension of that fleet, and concentrated their commercial exchanges with the Antilles (especially Cuba). Thus, in 1848, 45,16\% of all merchandise that arrived at the port of Barcelona from abroad came from an American port; and what is even more significant, $73,95 \%$ of the value of the goods exported that year from the port went to America. ${ }^{16}$ Therefore, although Barcelona was a Mediterranean city, its port at that time could be considered an Atlantic port. The Catalan economy was very open in those years: in 1847, for example, the value of Barcelona's port traffic represented a $17.2 \%$ of Catalonia's Gross Domestic Product. ${ }^{17}$ And that level of openness, which was close to the British, was only possible because of the American dimension of its international exchange.

One of the effects of the intense commercial effervescence of Barcelona's port was the rebirth of an insurance sector linked, by definition, to the financial sector, but also to the world of commerce: maritime insurance companies. After a long hiatus (1807-1838) in which there were no locally based maritime insurance companies in Barcelona, but representatives of companies headquartered elsewhere in Spain, three different maritime insurance corporations began operations in the Catalan capital: Barcelonesa de Seguros marítimos (1838), Catalana General de Seguros (1845) and Ibérica de Seguros (1846). Although they started as maritime insurance companies, all of them eventually incorporated 
the sale of fire and life insurance into their activities. These insurance companies founded in Catalonia are an example of the investment fervor that swept across the financial sector all across the peninsula. On 28 January 1848, a restrictive Public Limited Company Law led many of these new enterprises to collapse, but the three Catalan companies resisted. In general, the capital committed in these companies was high while outlay was low, until the Royal Decree of September 11th, 1850 that forced the outlay of $6 \%$ of the engaged capital.

The second effect was related to banking. Until then, the need for credit had been supplied mostly by merchant bankers. ${ }^{18}$ But the transformations detailed above led to the creation of banking institutions across the peninsula, beginning with Madrid and Barcelona. While the Madrid banks (the Banco de San Fernando and the Banco de Isabel II) were closely related to the financial turbulences of the public treasury, the Bank of Barcelona, created in 1844, was linked to the emerging Catalan industry and commercial expansion. ${ }^{19}$

Banks are supposed to serve as intermediaries between savers and investors, and to create money or means of payment. They lower the risks and costs assumed by economic agents because they have access to more and better information about both their clients and the needs of the market. The appearance of the Bank of Barcelona responded first and foremost to the needs of the Catalan economy, as its founders argued in the request that they sent the queen regarding the bank's opening, and the Royal Order that authorized it. ${ }^{20}$ The main partners, mostly merchants and traders, had an ample network established throughout the city, which facilitated the tasks of monitoring their clients, but they also had an ample network of contacts in Madrid. Manuel Lerena, an indiano who had made his fortune in Cuba and who was a member of the board of directors of the Bank of Barcelona, proved to be one of the more valuable contacts. His lobbying skills and his own network were 
fundamental in the court's passage of the Estatutos y Reglamento de Operaciones that, after a long wait, finally allowed the bank to open.

The novelty involved in the creation of a note issuing bank demanded not only an ample network of contacts and information, but a great deal of knowledge of the banking business. Such expertise characterized merchant bankers, who dealt with bills of exchange and promissory notes, and opened clients' current accounts to settle commercial operations. However, emission was something entirely new, and it entailed a series of technical details (for instance, ensuring that bills were not counterfeited), and economic knowhow (related to the economic impact of the monetary boost and liquidity that would ensue). Thus, the most rational solution was to bring together individuals whose different experiences and knowledge ensured that the necessary expertise was available — and this included local trader-bankers and indianos.

Some indianos had exercised various finance-related tasks in the Indies, such as drawing and transferring funds and notes, discounting bills of exchange, issuing unofficial mortgage loans, providing and acquiring insurances for maritime risk and sea loans, etc.). And when they returned to the peninsula, they brought this technical knowledge alongside their monetary capital, deploying it to successfully insert themselves in the commercial world of the Catalan capital and increase and often diversify their assets. They also brought a set of relations, of social, political and business networks threaded in America, that were very useful in Barcelona. Let us recall the volume of trade that went on with the Americas during this period. Indeed, as this article demonstrates, their financial and commercial expertise as well as the contact networks that they had constructed in American lands facilitated the integration and success of indianos in the heart of the Catalan business community, and especially, in the financial sector of its capital. ${ }^{21}$ 
Although insurance companies were not new projects in Barcelona, for enterprises of this sort had begun to operate in the eighteenth century, all had disappeared by the beginning of the nineteenth. And when in 1838 a locally based insurance company operated again in the capital, it was an entirely different kind of company. ${ }^{22}$ The Barcelonesa de Seguros Marítimos followed the standards established by the 1829 Commercial Code. It was constituted on Aril 29, 1838, by Pedro José Ortembach, Elias y Sobrinos, José Mataró, José Martorell and Jaime Tintó, and the other partners who signed the contract in which they committed all of their assets. ${ }^{23}$ Its starting capital was one million pesetas, and partners had to disburse $3 \%$ of the engaged capital in the act of the company's registration. The company did not appear to have been very active during its first few years. In the 1845 shareholders meeting, forty-seven shareholders or their representatives, who held a total of 188 shares, were present. ${ }^{24}$ The largest shareholders, with 10 shares each, were: Serafín Gonzálvez de Faria, Pedro Gil, Buenaventura Fontanals, Antonio Tinto (represented by Antonio Zulueta), Joaquín Castañer, Serra y Parladé and Francisco Fontanellas. According to company director Pedro José Ortembach, Juan Güell suggested increasing capital to issue more shares, for he knew investors who were eager to participate in the Barcelonesa. ${ }^{25}$ This suggestion was accepted, and the company's social capital was increased by fifty more shares. $^{26}$

The Barcelonesa limited its insurance operations to the maritime sector, but some of the other recently established insurance companies in the city did not. On December of 1845 , the Compañía Catalana General de Seguros was constituted to deal in all sorts of insurance, especially maritime, life, fire, and crop insurance policies; it also managed individuals' payments to opt out of the mandatory military service. ${ }^{27}$ It was constituted with a capital of 25 million pesetas divided into 10,000 shares, but the actual outlay was less than $10 \%$. Despite the diversity of its insurance operations, the company's founding partners decided 
to dedicate $40 \%$ of its abundant capital to maritime insurance. The registration act was signed by Manuel de Lerena, Ramon Maresch y Ros, José Plandolit, Girona Hermanos Clavé y Cia, Ignacio Flaquer y Cia, Gaudencio Masó y Pascual, Manuel Puig y Baucells, Juan Montagú, Serra Hermanos, and Carlos Torrens y Miralda. Following the model adopted by the Bank of Barcelona, the company's direction was divided among three people, while twelve partners formed an advisory board. At least ten shares were needed in order to have a voice in shareholder meetings; and regardless of the number of shares held, each shareholder had one vote.

The Compañía Ibérica de Seguros began its operations only months later: on February of 1846. With a starting capital of 3 million pesetas divided among 30,000 shares, it was founded by indiano Gerónimo Ferrer Valls, Spain's outgoing consul to Yucatan; landowner Ramón de Bacardí, and trader Rafael Patxot, all of whom constituted its board of directors. This company issued maritime insurance policies; it also insured crops against locust infestations and hailstones and "river floods and other plagues". Curiously, among the elements that were not covered by the company's insurance policies were "bank-notes, bills of exchange, and paper money." 28

\section{'Indianos' contribution to the transformation of the Catalan financial sector: monetary returns}

In this second section, we will assess the weight of the monetary resources invested by indianos in the financial institutions discussed so far. To do so, we must first analyze the role played by indianos in the Bank of Barcelona created in 1844, the lynchpin of Catalonia's modern financial system. Its activities as both an issuing and a commercial bank placed it at the forefront of Spain's banking sector at that time; and it inspired 
businessmen across the peninsula to create other issuing and commercial banks after the passage of the 1856 laws, which eased up regulations in the financial market.

Indeed, the Bank of Barcelona was a successful experiment that not only pointed the way forward but had immediate and far-reaching local and regional impacts. And a quick glance at its founders reveals that half of them were indianos who had moved to Barcelona after having grown rich in America. As a matter of fact, as we can see in Table 1, the capital contributed by indianos in the first Governing Board, surpassed that contributed by natives. The Board had 20\% of the Bank's capital, which was divided into 5.000 shares of 1.000 pesetas each: its indiano members controlled more than half of the Board's shares and approximately $12 \%$ of the Bank's total shares.

\section{[insert Table 1]}

But the Bank of Barcelona was not the only significant financial venture in which indiano capital played a significant role. Table 2 reveals that indiano participation in the three insurance companies created in Barcelona during this period was key to their foundation.

\section{[insert Table 2]}

Four of the eight members of the first governing board of the Compañía Barcelonesa de Seguros Marítimos were indianos; in the Catalana General de Seguros, all three directors were indianos, while four other indianos were part of its governing board (Flaquer, Masó, Plandolit y Serra). Indiano presence was also significant in the Compañía Ibérica de Seguros: four of its nine promoters were indianos (three of them had made their fortune in 
Cuba: Miguel Biada and Jaime Taulina in Havana; and Rafael Masó Pascual in Santiago), and the fourth, a member of the board of directors, had been the Spanish consul of Yucatan (Ferrer Valls). ${ }^{29}$

Although it is beyond the scope of this article to deal with the multiple companies founded in Barcelona after the insurance boom registered between 1855 and 1857, we want to point out that indianos were important founding members in those new ventures as well. There were, for instance, Lloyd Barcelonés de Seguros Marítimos, with Francisco Noriega, Salvador Masó, Baradat e Hijos and Pedro J. Plandolit; in La Aseguradora, Juan Biada and Jaime Badia participated, with this latter investor being also the company's first president; and Mariano Sirvent y Francisco Biada were in El Áncora de Seguros Marítimos. ${ }^{30}$

In sum, the lists and payrolls that identify the founders and directors of the Bank of Barcelona as well as the three insurance companies analyzed above reveal that indianos were key investors and participants in some of the most significant financial companies in the city at the time, the companies that most directly contributed to the mid-century modernization of the sector.

But how great was the aggregated wealth of the indianos who belonged to the Barcelona financial community? To find out, we have looked at official tax records, specifically, Barcelona's industrial and commercial tax registry (Matrícula de Contribución Industrial y de Comercio de la ciudad de Barcelona) for the year of 1852, because this is the closest year to the end of the period under study (1829-1855) for which there is ample and corroborated data. ${ }^{31}$ Of the taxpayers listed in the registry, we have selected those we knew for a fact were indianos - that is, those we knew had either been born in the Americas or had left the peninsula and then returned and settled in Barcelona. This means that there may 
be others in that list that we missed, for there is no complete list of indianos in Barcelona for this or any other period.

Thus, we have compiled a list of eighteen individuals and two general partnerships (Martorell y Bofill, and Vidal Quadras Hermanos) among Barcelona's indiano investors in joint-stock companies; and as can be seen in Table 3, we have also determined the total investment that each of these had made in Catalonia until then.

[insert Table 3]

Although this number may seem low, we want to point out that in quantitative terms, the impact of these men was substantial - in the world of finances, a handful of powerful investors can go a long way. Some of the city's most renowned fortune-holders of the time are in the list, such as José María Serra, the brothers Rafael and Gaudencio Masó Pascual, and Jaime Taulina. As we have seen, some of the men listed directly participated in enterprises that were fundamental in the modernization of the Catalan financial system. And on the other hand, as Table 3 reveals, their investments in public joint-stock companies across Catalonia added up to a considerable sum. This is further evidenced by a comparison between them and other industrial and commercial taxpayers. In 1852, there were only five taxpayers who paid more than 2,500 pesetas, and one of them was, again, Serra. These men were followed by a group of bankers and merchants (that included the prominent Marqués de Fontanellas and Girona Hermanos Clavé y Cía.), who paid around 2,000 pesetas eachand again, we find some of these men in our list. 
The broader group of indiano entrepreneurs and investors - those beyond the world of finances-is a bit more elusive, but we can still make some reflections on its heterogeneity, distinguishing at least three different profiles: (1) those who had been born in the principality and had returned after having made a fortune in the Americas (true indianos, so to speak); (2) the children of Catalan emigrants who had been born in the Americas and had later resettled in Catalonia (and were socially identified as indianos, even though they did not follow the dictionary definition); and (3) those non-Catalan Spaniards (and/or their children) who had made their fortune in the Americas and had decided to resettle in Barcelona or establish their businesses there upon their return. This was the case, for instance, of Rioja-born Manuel de Lerena, founder of the Bank of Barcelona; and later, of Antonio López, first Marques of Comillas. All of them were attracted by the Catalonian capital's economic dynamism, and they contributed to it with their wealth and their knowledge.

The first wave of indianos began arriving when continental America's war of independence broke out (this included wealthy entrepreneurs like Mariano Serra, and Biscay-born Pedro N. de Chopitea, who came from Chile, among many others). This wave included those who were expelled from most of the newly formed republics, especially from Mexico (mid1820 s) after the war was over. Starting in 1835 , a second wave of indianos began arriving individually and continually, especially from the Antilles, constituted mostly by businessmen who struck it rich in the Americas. Men and women like these, many with children, arrived in the city continually and incessantly. And if it is not already evident, we want to underline that the mythical image of indianos as old and extravagant men who returned from the Americas in their old age to marry younger women and live off rents in ostentatious homes, is just that: a myth, a legend. 


\section{Intangible returns and human capital: indianos' role in the financial sector's transformation}

The returns on human capital are very hard to measure, even today-so we can imagine how much harder it is to measure it in previous centuries. On the one hand, no statistics register data related to this phenomenon, so that those interested in the subject must gather and organize diverse kinds of information from various archives. On the other, that which constituted human capital in the period under study is not identical to what constitutes it today. ${ }^{32}$ In any case, we are interested in a basic definition of human capital and a simple but important argument: that the knowledge accumulated by the returning immigrants, based on their experience in the Americas as businessmen, landowners, etc., was an important resource for the Catalan - and Spanish — financial economy.

The Spanish financial historiography usually points at Great Britain and France as the main engines of both ideas and experiences for Spanish financiers (through trips, businesses, etc.). However, the important migratory flow between Spain and America should alert us to this altogether different source of knowledge - that gathered by those who, living in the New World, learned new ways of doing business and entered new branches of activity. Moreover, proximity to the United States, especially in the cases of Cuba and Puerto Rico, which concentrated the greater part of that migratory flow, played an important part in the set of accumulated experiences, and especially contacts and business partners, of returnees. The networks that they established in the Americas, as well as the shared experience of immigration among them, was a key element at the time of embarking on new projects once they returned to the peninsula, and more specifically, to Barcelona, which is our focus. Again, we have already shown that most of the foreign goods that entered the city's port 
came from the Americas, and that alone should alert us to the importance of having business and other contacts there.

We have identified two ways in which indianos invested their human capital: by transmitting the knowledge that they had acquired in the Americas to the business and social communities that they joined; and by expanding the networks of business contacts of these communities to include business opportunities across both sides of the Atlantic. Perhaps looking at a few specific cases that are representative of the set will better illustrate these two types of transfer of (American) intangibles. For the transfer of economic knowledge acquired in the Americas, we will look at Jaume Badia and Joan Güell; and for the expansion of business networks, the best examples are the brothers Alejo and Manuel Vidal Quadras.

The figure of Jaume Badia Padrines (1796-1863) has actually been studied before, and it is indeed a remarkable case. ${ }^{33}$ Jaume Badia represents the ample group of immigrants who left the country looking for better social and economic opportunities. To escape the Old Regime's choking hold on businesses, Badia's father left for the Americas. In 1812, the son followed in his footsteps, leaving Torredembarra when he was merely 16 years old for Matanzas, Cuba, where his paternal uncle Esteban Badia, one of the first Catalans to settle in that prosperous Cuban town, had established a successful business tied to the sugar industry that brokered deals, traded syrups and provided credit. When Esteban Badia died in 1818, Jaume took over the business, aided by administrator Don Tomás Gener, with whom he developed a profound economic and political relationship.

Gener was one of the most important men of Catalan origin in the city of Matanzas, without being the most economically powerful. He was at the center of a circle that promoted liberal political ideas, and Badia was not only a participant, but one of its most influential 
spokesmen. Jaume Badia and other Matanzas businessmen of this so-called "liberal group of Matanzas" promoted a newspaper, La Aurora, later called La Aurora del Yumurí, and he wrote under the pseudonym "El Observador" (the Observer), exposing the liberal ideas that he and his companions espoused. ${ }^{34}$ Here was a man who was not only interested in the success of his business, but in economic development and politics, who read whatever he could get his hands on, and whose experience in the world of the press helped him become a convincing ideologue and an effective divulger.

Towards 1839, soon after Badia returned from a forced exile (the result of a confrontation with the governor of Matanzas, Francisco Narváez de Bordese), Badia's liberal companions convinced him to go to the United States and investigate the advantages and disadvantages of the US banking system and the prospects of opening a note issuing bank of their own in the island. While abroad, he sent back ten letters that were published in La Aurora de Matanzas in 1840 and that contained descriptions of the US banking system and its successive crises, as well as the different positions held by the US political parties regarding the convenience of local note issuing banks and the need (or not) for national regulation. Badia's letters provide keen insights into the contemporary debates regarding the advantages and inconveniences of banks and fiduciary circulation, with comments that show his knowledge of the various writers and analysts of the period. He also analyzed the functioning of note issuing banks and commercial banks (which he called deposit banks); and he reflected upon the importance of trust in the banking business, the influence of the banking sector in the overall economy, the effects of banking expansions and contractions, and the erratic character of the banking sector regarding how easily it could all be swayed in one direction or another by a fortuitous event (a bad harvest), a legal change or reform, a war, etc. 
That same year, Gen. Baldomero Espartero forced Queen Regent Maria Christina into exile and assumed the government of the country as its Prime Minister (Isabella II was underaged), and Jaume Badia returned to Spain and joined the Progressive party, which finally had a chance to rule. In 1844, Badia participated in the procedures that culminated in the opening the Bank of Barcelona, and became the bank's first administrator, a position that he held until after the financial crisis of 1848. It is very probable that his expertise was the main reason why he was offered this position, along with his important social network.

Badia was part of the bank's governing board until his death in 1863. He also participated in other Barcelona-based companies, such as the Sociedad Catalana para el Alumbrado por Gas de Barcelona.

What is relevant about Jaume Badia in terms of this article is his banking expertise, the thorough knowledge, insights and ideas that Badia, the bank's first administrator, brought into the management and development of the Bank of Barcelona during its critical first years. His notions regarding privately run note-issuing banks are worth some reflection. In his final analysis, he rejected the banking model that operated in the United States during this period, preferring instead strict regulation and monopolies over free and unregulated emission. This perspective was congruent with that of the Bank of Barcelona regarding the emission of bank notes in Catalan territory.

Joan Güell Ferrer (1800-1872), another illustrious indiano, had vouched for Badia's suitability as the Bank of Barcelona's administrator, acting as his guarantor. Güell and Badia knew each other through their economic and financial activities, and were united by their common origins, for they were both originally from Torredembarra. Little else can be gathered from the available documentary record on Joan Güell Ferrer's personal life, for a significant part of his archive, which was located in the Palau Moja de Barcelona, was lost 
to a fire toward 1971. But thanks to the work of Pierre Vilar, we know that Güell exchanged long letters with Henry Carey, an American protectionist. ${ }^{35}$

We also know that Güell Ferrer left for America twice: the first time, the experience was not to his liking, so he returned to Barcelona and studied seamanship before crossing the Atlantic again, this time for Cuba, where he finally made his fortune. When he returned to Catalonia, which was around 1835, he participated in numerous businesses and ventures, among them, the Bank of Barcelona. It was he, as mentioned above, who convinced the board of directors of the Barcelonesa de Seguros Marítimos to increase the company's shares. Indeed, Güell was one of the most influential spokesmen of the Catalan industrial bourgeoisie, and his debates with liberals like Luis María Pastor are well-known. ${ }^{36}$

One of the clearest examples of the contributions made by indianos in the encouragement and modernization of the Catalan financial sector through the deployment of an ample business network is evidenced in the trajectory of the brothers Manuel and Alejo Vidal Quadras, founders of the Barcelona-based banking house Vidal Quadras Hermanos (18471912). ${ }^{37}$ Both brothers left their native Sitges in 1809 , when they were still children, and settled in Maracaibo (Venezuela), where they stayed until January of 1821, when the city was taken by Gen. Simon Bolívar's army. But instead of returning to Catalonia, they moved to Cuba, settling in Santiago, where they became successful traders with a commercial house that underwent various name-and partner-changes (Manuel Vidal Quadras, Vidal Hermanos y Cía., Vidal Hermanos e Hijo, Vidal y Compañía, Fabars Vidal y Cía., and Manuel Vidal e Hijo). This trading house became one of the most important of Cuba's Oriente region. But besides the ordinary commercial business of buying and selling merchandise, the Vidal Quadras brothers delved in some basic financial activities, namely, drafting bills of exchange and providing loans. 
It took the Vidal Quadras brothers quite some time before they decided to resettle permanently in Barcelona. They first travelled to the city in 1833, so that their children (Manuel and Antonio Vidal Quadras, and Alejo, Ramon, and their sister Carolina Vidal Quadras) could go to school. Six years later, on April of 1839, the brothers purchased two land plots near the city port, where the coastal wall had been, and ordered the construction of a five-story house in each before they themselves arrived. What better calling card would introduce them to their Barcelona neighbors than the evident solvency demonstrated by these seafront edifices?

While this construction was underway, the Vidal Quadras trading house continued operating in Santiago, increasingly administered by Manuel Vidal Quadras's firstborn son, Manuel Vidal Quadras Ramon. Two and a half years later, on January 1847, Vidal Quadras Hermanos opened its doors in one of the buildings that had already been finished in the Barcelona coastal front. And soon after, the company consolidated itself as an important banking house: in only one year, the Banca Vidal Quadras Hermanos ranked eleventh in the (hypothetical) list of the city's major businesses in the market of bills of exchange and promissory notes and banknotes. According to one study, in 1848 Banca Vidal Quadras had put out a total sum of 2,5 million pesetas. Twelve years later, that sum was multiplied by nine, reaching a staggering 22,8 million pesetas. ${ }^{38}$ The level of and quantity of operations carried out by Vidal Quadras was so intense, that that year, 1860, they occupied the first place in the market, well ahead of the Sociedad Catalana General de Crédito.

Vidal Quadras managed this tremendous growth and consolidation in a very brief period (a little over ten years), but they had not started from scratch. They not only had a large starting capital, they also had the experience and contacts acquired during their long years of operation in America (first in Maracaibo and then in Santiago de Cuba). The capital 
stock of the Banca Vidal Quadras Hermanos went from 150.000 pesetas to 1.150 .000 pesetas in its first capital-increase reform in 1861 . That is, in a little over a decade, it had multiplied by seven. Part of that remarkable rise reflected the incorporation of the capital progressively liquidated from their properties and interests in Cuba, while another part came from the reinvestment of the profit accumulated from the rest of their financial activity in Barcelona.

The experience of the Vidal Quadras brothers evidences how the network of contacts built during the American sojourn of indianos was an essential resource in their financial activity. But it also shows that American wealth facilitated the extension of that network. Carolina Vidal, sister to indiano bankers Alejo and Ramón, had stayed in Barcelona since 1833 — during her father and uncle's first return trip to the city — and on June of 1844, she had married the up-and-coming Catalan entrepreneur Manuel Girona Agrafel. An important professional and social contact for her family, Manuel Girona was the main promoter of the Bank of Barcelona. Marriages such as this were frequently carried out to broaden and deepen networks and links between the two groups - those who came from America, and those who had not left Catalonia—in recognition of the fact that each had a particular knowledge, experience and contacts that was useful to the other. Starting in the midnineteenth century, Catalonia saw the emergence of a new, industrial and commercial bourgeoisie that was, we could say, mestiza. Its heirs would constitute the model of enterprising businessman that Vicens Vives analyzed in his day as the characteristic vector of nineteenth century Catalonia. ${ }^{39}$

\section{Conclusion}


Although the impact of returned indianos' contribution to the Spanish economy is generally acknowledged, the difficulties in measuring this contribution generate a gap in the historiography. In this article, we have made a preliminary exercise to identify variables that can help us measure this impact in the Catalan financial world, but also in other sectors of the economy. As part of this approximation, we have looked at indiano participation in governing boards and the direction of bank and insurance companies; the commercial and industrial taxes paid by these men and women; and the investments that they carried out in the period under study.

We have also addressed the significance of indiano capital in the foundation of various financial companies. The case of the Bank of Barcelona is crucial, not only because indiano participation in its foundation, governing board, and administration, but because the Bank was a key modern (and modernizing) institution in Catalonia. Extending the analysis across time would allow us to include other companies and compare the conclusions that can be drawn from this work. After all, the laws of 1856 multiplied credit companies as well as various other financial and industrial institutions and companies, and we are yet to determine indiano capital's participation in these. But we can surmise that it was equally important, for wealthy indiano businessmen continued arriving and investing in the city through the 1870s. Antonio López y López, Marques of Comillas, is undoubtedly a paradigmatic example.

On the other hand, the set of abilities, knowledge, and social networks that indianos brought into the Catalan economy has also proven itself formidable. We have been able to trace and follow the trajectories of many individuals, a very difficult and demanding task that seems never-ending. Through this work, we have identified two major areas in which the human capital invested by indianos in the Catalan economy was particularly important: 
knowledge and social networks. To represent this in the article, we selected two indianos whose knowledge, acquired in the Americas, was both evident and extensive: J. Badia and J. Güell; and another case which showed how social networks made in the Americas could significantly help a business: the Vidal Quadras brothers. These cases show how living and working in the Americas made it possible for individuals to become extremely successful businessmen in the peninsula, specifically, in Barcelona; and how through their success, the Catalan financial sector began walking down the path of modernization. 
${ }^{1}$ Bahamonde and Cayuela, Hacer las Américas, 141-182.

${ }^{2}$ Soler, "Desenvolupament comercial" and Soler, "Comerciants i fabricants", 109-136.

${ }^{3}$ Solà, “Os 'americanos', 152-153. Rodrigo, Indians a Catalunya, 41-217.

${ }^{4}$ Núñez, "Emigración de retorno", 28-39.

${ }^{5}$ Sjaastad, "The costs", 83-85.

${ }^{6}$ Becker, "Human Capital", 39-40 and 231-232.

${ }^{7}$ Blasco and Sudrià, El Banco de Barcelona, 33-88.

${ }^{8}$ Sala, Un siglo, 187-202.

${ }^{9}$ Badenes, "Capitals indians", 39-61.

${ }^{10}$ Nadal, El fracaso, 188-225.

${ }^{11}$ Benet and Martí, Barcelona a mitjan segle XIX, vol. II, 5-222.

${ }^{12}$ Pascual, Los caminos, 47-250.

${ }^{13}$ Tortella, Los orígenes, 163-183.

${ }^{14}$ Rodrigo, "Navieras y navieros", 88-90.

${ }^{15}$ Fradera, Indústria i mercat, 230-297.

${ }^{16}$ Junta de Comercio, Balanza mercantil.

${ }^{17}$ Carreras and Yáñez, "El puerto", 85.

${ }^{18}$ Regarding merchant bankers, see García, "Banqueros y comerciantes"; for more on the means of payment used, see Castañeda y Tafunell, "Un instrument", and Castañeda, "Esplendor y ocaso".

${ }^{19}$ For Madrid banks, see Tedde de Lorca, "Banco de San Carlos", 79-361 and Tedde de Lorca, "Banco de San Fernando", 25-130 and 197-261; Tortella, "Los orígenes" and 
Zumalacarregui, "Banco de Isabel II”. For Barcelona banks, see Blasco-Martel and Sudrià, El Banco de Barcelona, 21-25 and 204-214.

${ }^{20}$ The Bank of Barcelona's documents are presently housed in the Arxiu Nacional de Catalunya. For more on this source, see Blasco-Martel, "Una nueva fuente". The Royal Order cited was signed on May 1, 1844.

${ }^{21}$ For the importance of this network in the Catalan financial sector, see Badia-Miró et al, "Centrality”, 496-497; on the significance of banking knowledge, see Blasco-Martel, “'Retornos' de América", 136-149.

${ }^{22}$ Sala, Un siglo, 187-197.

${ }^{23}$ Archivo Histórico de Protocolos de Barcelona, Jose Manuel Planas Compte, 29.04.1838.

${ }^{24}$ Archivo Histórico de Protocolos de Barcelona, José Manuel Planas Compte, 13.12.1845.

${ }^{25}$ The director's name is not explicitly stated, but we presume that it was P. Ortembach, because in another deed drawn up by José Manuel Planas Compte, on September 21, 1839, it was he who gave José Riba power of attorney on behalf of the company.

${ }^{26}$ Archivo Histórico de Protocolos de Barcelona, José Manuel Planas Compte, January 1846, fol. 18 and ss. The company's capital was increased to 1.500 .000 pesetas.

${ }^{27}$ Archivo Histórico de Protocolos de Barcelona, José Manuel Planas Compte, December 1845, fol. 478 .

${ }^{28}$ Archivo Histórico de Protocolos de Barcelona, José Manuel Planas y Compte, escritura de febrero 1846.

${ }^{29}$ Miguel Biada and Jaime Taulina had gotten rich in Havana and Rafael Masó Pascual in Santiago de Cuba; Ferrer Valls had been consul at Yucatan.

${ }^{30}$ Sala, Un siglo, 276-289. 
${ }^{31}$ For a full description of this tax, see Estapé, La reforma tributaria, 129-161. For the published 1852 data, see the Real Orden de 10 de febrero de 1852 (published on Boletín Oficial de la Provincia de Barcelona on April 23, 1852).

${ }^{32}$ For a recent analysis, see Dustmann, Fadlon and Weiss, "Return migration", 61-67.

${ }^{33}$ Blasco-Martel, “'Retornos' de América” and Epistolari, 36-42.

${ }^{34}$ González, Los catalanes, p.53.

${ }^{35}$ Vilar, Catalunya, vol I, 68.

${ }^{36}$ Artal, "Pensament econòmic", 159-179.

${ }^{37}$ Castañeda and Rodrigo, "Los Vidal Quadras", 125-142; Rodrigo, "Una saga", 109-119.

${ }^{38}$ Castañeda and Rodrigo, "Los Vidal Quadras", 132-133.

${ }^{39}$ Vicens and Llorens, Industrials, 124-142.

\section{REFERENCES}

Artal, Francesc. "Pensament econòmic català, 1840-1898. Del proteccionisme al regionalisme econòmic.” $\mathrm{PhD}$ diss., Universitat de Barcelona, 1993.

Badenes, Carles. "Capitals indians al sistema financer català (1833-1883).” Dissertation for obtaining the Master degree in World History, Universitat Pompeu Fabra, 2011. 
Badia-Miró, Marc, Blasco, Yolanda, Lozano, Sergi and Soler, Raimon. "Centrality and investment strategies at the beginning of industrialisation in mid-nineteenth-century Catalonia," Business History 52/3 (2009): 493-515.

Bahamonde, Angel and José Cayuela. Hacer las Américas. Las élites coloniales españolas en el siglo XIX. Madrid: Alianza, 1992.

Becker, Gary. Human Capital: A Theoretical and Empirical Analysis with Special Reference to Education. Chicago: Chicago University Press, 1993 [1964].

Benet, Josep and Casimir Martí. Barcelona a mitjan segle XIX: el movement obrer durant el Bienni Progressista, 1854-1856. Barcelona: Curial, 1976.

Blasco-Martel, Yolanda. "Una nueve fuente bancaria: el Banco de Barcelona," Revista de Historia Industrial 23 (2003): 199-206.

Blasco-Martel, Yolanda. “'Retornos' de América, banca y capital humano: el caso de Jaime Badia," Historia Social, 59 (2007): 125-150.

Blasco-Martel, Yolanda. Epistolari de Jaume Badia: el pensament bancari en el segle XIX. Torredembarra: Cossetània, 2009.

Blasco-Martel, Yolanda and Carles Sudrià. El Banco de Barcelona (1844-1874), historia de un banco emisor. Madrid: Lid, 2010. 
Carreras, Albert and César Yáñez. "El puerto en la era industrial: una síntesis histórica," in Economía e historia del puerto de Barcelona. Tres estudios, edited by Joan Clavera, Albert Carreras, Josep Maria Delgado and César Yáñez, 81-157. Madrid: Civitas-Port Autònom de Barcelona, 1992.

Castañeda, Lluís. "Esplendor y ocaso del mercado de letras de cambio en la Barcelona del siglo XIX.” PhD diss., European University Institut, 2001.

Castañeda, Lluís and Martín Rodrigo. "Los Vidal Quadras: familia y negocios, 1833-1871," Barcelona Quaderns d'Història, 11 (2004): 115-144.

Castañeda, Lluís and Xavier Tafunell. "Un instrumento dinamizador de los mercados de crédito: los pagarés a mediados del siglo XIX." Paper presented at the VI Congress of the Asociación Española de Historia Económica, Girona, Spain, September 15-17, 1997.

Dustmann, Christian, Itzhak Fadlon and Yoram Weiss. "Return Migration, Human Capital Accumulation and the Brain Drain," Journal of Development Economics, 95 (2011): 58-67.

Estapé, Fabián. La reforma tributaria de 1845. Madrid: Instituto de Estudios Fiscales, 1971.

Fradera, Josep Maria. Indústria i mercat: les bases comercials de la industria catalana moderna, 1814-1845. Barcelona: Crítica, 1987. 
García, José Ramón. "Banqueros y comerciantes banqueros, clave oculta del funcionamiento del sistema bancario español del siglo XIX," Moneda y Crédito, 175 (1985): 59-85.

González, Juan Francisco. Los catalanes y el grupo liberal de Matanzas. Matanzas: Ediciones Matanzas, 1998.

Junta de Comercio. Balanza mercantil de la importación y exportación verificada por el puerto y aduana de Barcelona en el año de 1848. Barcelona, 1849.

Nadal, Jordi. El fracaso de la revolución industrial en España, 1814-1913. Barcelona: Ariel, 1975.

Núñez, Xose Manuel. "Emigración de retorno y cambio social en la península Ibérica," Migraciones \& Exilios. Cuadernos AEMIC 12/1: (2000): 27-66.

Pascual, Pere. Los caminos de la era industrial: la construcción y financiación de la red ferroviaria catalana (1843-1898). Barcelona: Edicions Universitat de Barcelona, 1999.

Rodrigo, Martín. Indians a Catalunya: capitals cubans en l'economia catalana. Barcelona: Fundació Noguera, 2007.

Rodrigo, Martín. "Navieras y navieros catalanes en los primeros tiempos del vapor, 18301870," TST, Transportes, Servicios y Telecomunicaciones, 13 (2007): 62-92. 
Rodrigo, Martín. "Una saga de banqueros: la familia Vidal Quadras," Historia Social, 69 (2009): 99-119.

Sala, Mario. Un siglo de seguros marítimos barceloneses en el comercio con América (1770-1870). Madrid: Fundación Mapfre, 2012.

Sjaastad, Larry A. "The Costs and Returns of Human Migration," Journal of Political Economy, 70/5 (1962): 80-93.

Solà, Angels. “Os 'americanos' cataláns e o seu impacto económico en Cataluña ó longo do século XIX," Estudios Migratorios, 11-12 (2001): 141-168.

Soler, Raimon. "Desenvolupament commercial i creixement industrial a Catalunya. Vilanova i la Geltrú, 1839-1914," Dissertation for obtaining the Master degree in Economic History, Universitat de Barcelona, 1995.

Soler, Raimon. "Comerciants i fabricants. Una reflexion sobre l'origen commercial del capital industrial: el cas de Vilanova i la Geltrú," Recerques 36 (1998): 109-136.

Tedde, Pedro. El Banco de San Carlos, 1782-1829. Madrid: Banco de España, 1988.

Tedde, Pedro. El Banco de San Fernando, 1829-1856. Madrid: Alianza, 1999.

Tortella, Gabriel. Los orígenes del capitalismo en España: banca, industria y ferrocarriles en el siglo XIX. Madrid: Tecnos, 1982. 
Vicens, Jaume and Montserrat Llorens. Industrials i politics del segle XIX. Barcelona: Teide, 1958.

Vilar, Pierre. Catalunya dins l'Espanya moderna. Barcelona: Edicions 62, 1964.

Zumalacarregui, Leopoldo. El Banco de Isabel II y la crisis de la banca de emisión española de 1847. Madrid: [s.n.], 1952. 


\section{TABLES}

Table 1: Indiano Participation in the foundation of the Bank of Barcelona

\begin{tabular}{|c|c|c|c|}
\hline \multicolumn{4}{|c|}{$\begin{array}{l}\text { BANK OF BARCELONA ( } 1845) \text { first GOVERNING BOARD. } \\
\text { Capital } 1 \text { million duros ( } 25 \% \text { outlay). } 1 \text { share }=200 \text { duros }\end{array}$} \\
\hline INDIANOS & SHARES & NON-INDIANOS & SHARES \\
\hline Serra, Josep M. & 100 & Girona, Manuel & 100 \\
\hline Plandolit, Josep Rafael & 100 & Pascual, Sebastià Anton & 40 \\
\hline Flaquer, Marià & 40 & Coma, Tomàs & 40 \\
\hline Güell, Joan & 100 & Peyra i Mach, Agustí & 40 \\
\hline Badia, Jaume & 40 & Parladé, Josep & 100 \\
\hline Roig i Rom, Miquel & 40 & Serra i Farreras, Josep & 50 \\
\hline Lerena, Manuel de & 100 & Villavecchia, Ignasi & 100 \\
\hline Gonzàlvez de Faria, Serafí & 40 & Ricart i Guitart, Jaume & 40 \\
\hline TOTAL & 560 & & 490 \\
\hline
\end{tabular}

Source: This table was made using data from Blasco-Martel and Sudrià, El Banco de Barcelona.

Table 2: Indiano participation in the formation of insurance companies

\begin{tabular}{|c|c|c|c|}
\hline $\begin{array}{l}\text { COMPAÑÍA BARCELO } \\
\text { first GOVERNING BOAI }\end{array}$ & $\begin{array}{l}\text { ESA DE SEGUR } \\
\text { D. (Capital } 250.00\end{array}$ & $\begin{array}{l}\text { OS MARÍTIMOS (1838): } \\
0 \text { duros }=1.250 .000 \text { peset }\end{array}$ & $6 \%$ outlay) \\
\hline$\overline{\text { INDIANOS }}$ & $\begin{array}{c}1849 \text { CAPITAL } \\
\text { (in pesetas) }\end{array}$ & NON-INDIANOS & $\begin{array}{l}1849 \text { CAPITAL } \\
\text { (in pesetas) }\end{array}$ \\
\hline $\begin{array}{l}\text { Gonzálvez de Faria, } \\
\text { Serafín }\end{array}$ & & Castañer, Joaquín & \\
\hline Roig Rom, Miguel & $(10.000)$ & Fontanellas, Francisco & $(50.000)$ \\
\hline Plandolit, José & & Soler, Sebastián & \\
\hline Sirvent, Mariano & $(10.000)$ & Gil Babot, Pedro & $(50.000)$ \\
\hline $\begin{array}{l}\text { CATALANA GENERAL } \\
\text { (Capital: } 5 \text { million duros }\end{array}$ & $\frac{\text { E SEGUROS (18 }}{25.000 .000 \text { peseta }}$ & $\begin{array}{l}\text { 845): first GOVERNING F } \\
\text { is, } 6 \% \text { outlay) }\end{array}$ & $\underline{\mathrm{RD}}$ \\
\hline Masó, Gaudencio (Dir.) & & Maresch Ros, Ramon & \\
\hline Noriega, Francisco (Dir.) & & Pujol Clauxet, Pablo & \\
\hline Flaquer, Ignacio & & Puig Baucells, Manuel & \\
\hline Masó, Salvador & & Marqués de Sentmenat & \\
\hline Plandolit, José & & Soler, Salvador José & \\
\hline Serra, José M. & & Torrents Miralda, Carlos & \\
\hline Lerena, Manuel (Dir.) & & Villavecchia, Ignacio & \\
\hline & & Marin Clavé, Juan Bta . & \\
\hline
\end{tabular}




\begin{tabular}{|l|r|l|r|}
\hline & $\begin{array}{c}1853 \text { CAPITAL } \\
\text { (in pesetas) }\end{array}$ & & $\begin{array}{c}1853 \text { CAPITAL } \\
\text { (in pesetas) }\end{array}$ \\
\hline Biada, Miguel & $(150.000)$ & de Bacardí, Ramon (Dir) & \\
\hline Taulina Villalonga, Jaime & $(375.000)$ & Durán, Buenaventura & $(100.000)$ \\
\hline Masó Pascual, Rafael & $(50.000)$ & Colom Roca, José & \\
\hline $\begin{array}{l}\text { Ferrer Valls, Gerónimo } \\
\text { (Dir) }\end{array}$ & & Comas, Francisco & \\
\hline & & Patxot, Rafael (Dir) & \\
\hline
\end{tabular}

Source: This table was made using data from Sala, 2012 and from the database Empreses $i$ empresaris de Catalunya al segle XIX.

Note: Company accounting used duros or reales, where 1 duro $=5$ pesetas $=20$ reales.

Table 3: Indianos' industrial taxes and commercial investments in public joint-stock companies, 1852.

\begin{tabular}{|l|r|r|}
\hline INDIANO & $\begin{array}{c}\text { TAXES PAID, 1852 } \\
\text { (in pesetas) }\end{array}$ & $\begin{array}{c}\text { INVETMENT IN PUBLIC } \\
\text { JOINT-STOCK } \\
\text { COMPANIES (in pesetas) }\end{array}$ \\
\hline Serra, Josep M. & 3.556 & 486.500 \\
\hline Masó, Salvador & 2.094 & $\mathrm{n} / \mathrm{d}$ \\
\hline Plandolit, Josep Rafael * & 2.028 & -- \\
\hline Masó Pascual, Rafael & 1.883 & 23.000 \\
\hline Masó, Gaudencio & 1.754 & 123.000 \\
\hline Flaquer, Mariano & 1.689 & 365.000 \\
\hline Martorell y Bofill & 1.603 & 150.000 \\
\hline Vidal Ribas, José & 1.603 & 190.200 \\
\hline Vidal Quadras Hermanos & 1.603 & $\mathrm{n} / \mathrm{d}$ \\
\hline Roig Rom, Miquel & 1.369 & 27.500 \\
\hline Taulina Villalonga, Jaime & 1.258 & 63.530 \\
\hline Noriega, Francisco & 1.117 & 90.250 \\
\hline Güell, Joan & 323 & $\mathrm{n} / \mathrm{d}$ \\
\hline Sirvent, Mariano & 185 & 10.250 \\
\hline Lerena, Manuel de ** & $\mathrm{n} / \mathrm{d}$ & 759.250 \\
\hline Gonzàlvez de Faria, Serafín & $\mathrm{n} / \mathrm{d}$ & 25.000 \\
\hline Badia, Jaume & $\mathrm{n} / \mathrm{d}$ & $\mathrm{n} / \mathrm{d}$ \\
\hline Biada, Miguel & $\mathrm{n} / \mathrm{d}$ & $\mathrm{n} / \mathrm{d}$ \\
\hline Bofill Pintó, Juan Manuel & $\mathrm{n} / \mathrm{d}$ & $\mathrm{n} / \mathrm{d}$ \\
\hline
\end{tabular}




\begin{tabular}{|l|r|r|}
\hline Ferrer Valls, Gerónimo & $\mathrm{n} / \mathrm{d}$ & $* * *$ \\
\hline
\end{tabular}

Source: This table has been constructed using data from the Contribución Industrial y Territorial [Industrial and Territorial Tax Registry] of 1852, and the investment data available in the database of the Department of History and Economic Institutions of the University of Barcelona.

* José Rafael Plandolit died in 1846; this data corresponds to the taxes paid by Plandolit Hermanos, his commercial firm. The Bank of Barcelona's direction remained in the family.

**Manuel de Lerena was also the manager of the Compañía General de Cataluña (insurances), with a fiscal obligation of 11.660 reales $=2.915$ ptas.

*** Investments in La Ibérica (1846) and in the Canal de Urgell (1852) are registered, but no data is provided regarding their amount. 